\title{
MODUL DIGITAL INTERAKTIF BERBASIS ARTICULATE STUDIO'13: PENGEMBANGAN PADA MATERI GERAK MELINGKAR KELAS X
}

\author{
Irwandani $^{1}$, Sri Latifah ${ }^{2}$, Ardian Asyhari ${ }^{3}$, Muzannur ${ }^{4}$, Widayanti ${ }^{5}$ \\ 1,2,3,4 Pendidikan Fisika, Fakultas Tarbiyah dan Keguruan, UIN Raden Intan Lampung, Indonesia \\ ${ }^{5}$ Pascasarjana FKIP Fisika, Universitas Lampung, Indonesia \\ e-mail: irwandani@radenintan.ac.id
}

Diterima: 8 Juli 2017. Disetujui: 8 Oktober 2017. Dipublikasikan: 28 Oktober 2017

\begin{abstract}
Abstrak: Tujuan penelitian ini adalah untuk menghasilkan produk modul digital interaktif berbasis Articulate Studio'13 pada mata pelajaran fisika materi gerak melingkar yang berkualitas dan menarik. Penelitian ini merupakan jenis penelitian dan pengembangan (R\&D) dengan memodifikasi 10 tahapan yang ada menjadi 7 tahapan yaitu; potensi dan masalah, pengumpulan informasi, desain produk, validasi desain, revisi desain, uji coba produk, dan revisi produk. Pembatasan tahapan ini dilakukan berdasarkan kebutuhan dan tujuan penelitian itu sendiri. Berdasarkan hasil validasi produk, diperoleh kesimpulan bahwa modul digital interaktif berbasis articulate studio'13 pada mata pelajaran fisika materi gerak melingkar diakategorikan sangat layak untuk digunakan. Persentase yang diperoleh dari ahli materi fisika sebesar $84,67 \%$, dari ahli media pembelajaran sebesar $85,56 \%$, dan dari praktisi pendidikan sebesar $84,1 \%$. Produk tersebut kemudian diujicobakan dalam skala kecil dan diperoleh persentase kemenarikan sebesar 84.4\%. Selanjutnya, dalam uji coba skala besar diperoleh persentase kemenarikan sebesar 85,0\%. Berdasarkan hasil tersebut, diperoleh kesimpulan bahwa modul digital interaktif berbasis Articulate Studio'13 pada mata pelajaran fisika materi gerak melingkar dapat digunakan sebagai modul pembelajaran.
\end{abstract}

Kata Kunci: articulate studio'13, gerak melingkar, interaktif, modul digital

\section{ARTICULATE STUDIO' 13-BASED INTERACTIVE DIGITAL MODULE: THE DEVELOPMENT OF CIRCULAR MOTION MATERIAL FOR THE TENTH GRADE STUDENTS}

\begin{abstract}
The aims of this research is to produce interactive digital modul based on Articulate Studio '13 on quality and interesting circle motion subject of physics learning. This is Research and Development $(R \& D)$ research by modifying 10 stages that exists into 7 stages, they are: potential and problem, information gather, product design, design validation, design revision, product testing, and product revision. The limitation of stages is done based on the need and the purpose of the research itself. Based on the result validation product, concludes that digital interactive modul of Articulate Studio'13 on circle motion subject is categorized very eligible to used. The gain percentages are from physics experts are $84,67 \%$, from learning media experts are 85,56\%, and from education experts are 84,1\%. Then, the product is tested on small scale and gained interesting percentage at $84,4 \%$. Later, on large scale gained interesting percentage at $85,0 \%$. Based on those result, it can be conclude that interactive digital modul based on Articulate Studio'13 on circle motion subject of physics learning can be used as learning modul.
\end{abstract}

C 2017 Pendidikan Fisika, FTK UIN Raden Intan Lampung

Keywords: articulate studio'13, circular motion, digital modul, interactive.

\section{PENDAHULUAN}

Pendidikan merupakan investasi penting dan memiliki peranan strategis bagi terwujudnya sumber daya manusia yang berkualitas (Ayudia, 2014; Nurul Qomariah, 2012). Pendidikan yang baik berkorelasi pada semakin tingginya capaian kualitas sumber daya manusia (Krismiyati, 2017). Membuat keputusan untuk terus berinovasi dalam pembelajaran merupakan pilihan yang harus dipilih oleh pendidik (Asyhari \& 
Diani, 2017). Penguasaan terhadap ilmu pengetahuan dan teknologi menjadi indikator keberhasilan dalam pencapaian kualitas pendidikan dan peningkatan sumber daya manusia tersebut (Byun, Sung, \& Park, 2017; Heeks \& Stanforth, 2015; Ngafifi, 2014; Ulfah, 2012).

Ilmu fisika merupakan salah satu bidang ilmu yang penting untuk dikuasai. Namun, bagi sebagian besar peserta didik, ilmu fisika masih dianggap sulit untuk dipelajari (Fathurohman, 2014; P, Sunaryo, \& Iswanto, 2012; Sari, Surantoro, \& Ekawati, 2013). Kesulitan peserta didik umumnya berasal dari anggapan bahwa ilmu fisika banyak memuat rumus dan teori yang sulit dipahami (Lubis \& Derlina, 2016; Suroso, 2016).

Secara umum, ilmu fisika membahas tentang gejala-gejala alamiah pada kehidupan sehari-hari maupun fenomenafenomena yang terjadi di alam semesta. Berdasarkan fenomena yang diamati, ilmu fisika terbagi menjadi dua, yaitu fenomena yang terlihat nyata oleh panca indra dan fenomena yang tidak terlihat panca indra atau bersifat abstrak (Aulliyah, Sutarto, \& Harijanto, 2015). Fenomena atau gejala fisika yang bersifat abstrak membutuhkan media tambahan untuk menjelaskan konsepnya. Kesulitan memahami pelajaran fisika umumnya disebabkan karena kurangnya inovasi bahan ajar yang digunakan pendidik dalam proses pembelajaran (Purnamasari, An'nur, \& M., 2016; Rahayu, Prihandono, \& Gani, 2017; Yoto, Zulkardi, \& Wiyono, 2015).

Senada dengan hasil observasi di MAN 1 Bandar Lampung pada pembelajaran fisika bahwa hampir seluruh siswa mempunyai komputer dan sebagian besar peserta didik mempunyai laptop. Adanya fasilitas yang memadai belum mampu menunjang pelaksanaan pembelajaran dikelas maupun mandiri. Pendidik sebagai pengajar menggunakan bahan ajar dan media konvensional dalam menyampaikan materi pelajaran.
Berdasarkan observasi tersebut peserta didik membutuhkan bahan ajar yang menarik, inovatif dan mudah digunakan untuk menyampaikan pesan dengan baik sebagai visualisasi yang tepat untuk memberikan pemahaman kepada siswa (Asyhari, Irwandani, \& Saputra, 2016).

National Center For Vocational Education Research Ltd (Praswoto, 2014) mendefinisikan bahan ajar sebagai segala bentuk bahan yang digunakan untuk membantu pendidik atau instruktur dalam melaksanakan proses pembelajaran di kelas. Bahan ajar adalah merupakan seperangkat materi yang disusun secara sistematis sehingga tercipta lingkungan/ suasana yang memungkinkan peserta didik untuk belajar (Nasional, 2008a). Jadi bahan ajar merupakan segala bentuk bahan yang dapat menunjang pembelajaran.

Salah satu bentuk bahan ajar diantaranya adalah modul (Tania \& Susilowibowo, 2017). Modul saat ini terbagi dalam dua kategori, yaitu modul yang bersifat cetak dan modul digital. Modul yang bersifat digital mempunyai kelebihan mampu untuk menampilkan beberapa materi menggunakan media pembelajaran yang bersifat interaktif (Aprilliyah \& Wahjudi, 2014; Sugianto, Abdullah, Elvyanti, \& Muladi, 2013; Sujanem, Suswandi, \& Ganesha, 2012).

Media pembelajaran interaktif mempermudah pendidik mengajarkan materi yang bersifat abstrak (Permana, Johar, \& Bunyamin, 2014) Beberapa media pembelajaran interaktif dinilai mampu dalam menjelaskan fenomenafenomena yang terjadi di alam dan menghadirkannya di dalam kelas (Wulandari, Susilo, \& Kuswandi, 2016). Salah satu contoh fenomena yang membutuhkan penjelasan lebih lanjut dan membutuhkan bantuan media interaktif adalah fenomena gerak melingkar (Desy, Desnita, \& Raihanati, 2015; Syafi'i \& Nasir, 2016). 
Berdasarkan latar belakang tersebut, diperlukan upaya untuk meningkatkan peranan media pembelajaran (Kristanti, Subiki, \& Handayani, 2016; Suprapto, 2006) dalam membelajarkan konsep fisika, terutama untuk penjelasan konsep yang membutuhkan penjelasan melalui media interaktif. Berdasarkan permasalahan yang telah dipaparkan tersebut, maka peneliti merasa perlu untuk mengembangkan sebuah modul pembelajaran digital interaktif untuk materi fisika. Adapun letak kebaruan dari penelitian ini, modul digital interaktif akan dikembangkan menggunakan software Articulate Studio'13 dengan materi fisika gerak melingkar untuk kelas X SMA.

Program Articulate memiliki kelebihan yaitu smart brainwere yang sederhana (Gambar 1). Adapun prosedur tutorial interaktif melalui template yang dapat di publish secara offline maupun online sehingga memudahkan pengguna memformatnya dalam bentuk laman personal, $\mathrm{CD}$, word prosessing dan Learning Manajemen System (LMS) (Fachrory Akbar Ghozali, 2016).

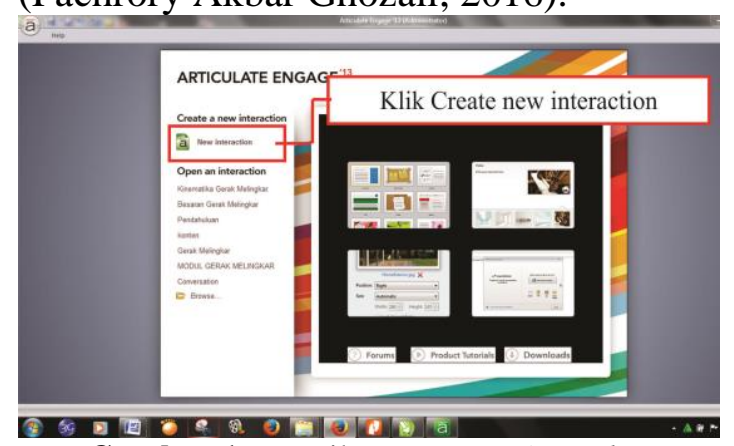

Gambar 1 Tampilan Program Articulate

\section{METODE PENELITIAN}

Tujuan dari penelitian ini adalah untuk menghasilkan produk Modul Digital Interaktif Berbasis Articulate Studio'13 yang berkualitas dan menarik untuk peserta didik. Penelitian ini menggunakan metode penelitian dan pengembangan (Researchand and Development), langkah-langkahnya meliputi: 1) Potensi dan masalah, 2) Pengumpulan data, 3)
Desain produk, 4) Validasi desain, 5) Revisi desain, 6) Uji coba produk, 7) Revisi Produk, 8) Uji coba Pemakaian, 9) Revisi produk, 10) Produksi massal (Sugiono, 2011).

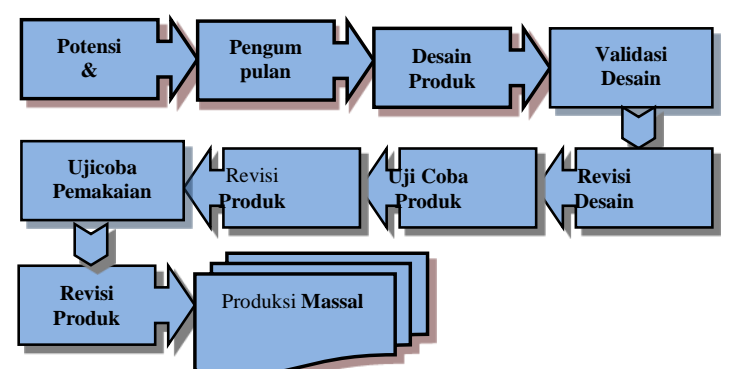

Gambar 2 Langkah-langkah penggunaan metode research and development $(\mathrm{R} \& \mathrm{D})$.

Berdasarkan analisis kebutuhan dan tujuan penelitian, pada penelitian ini melihat kevalidan produk yang dikembangkan, tanpa melihat keefektifitasan produk maka peneliti membatasi langkah penelitian dan pengembangan dari (10) sepuluh langkah menjadi (7) tujuh langkah, senada dengan penelitian sebelumnya (Huda, Fadiawati, \& Tania, n.d.; Irwandani \& Juariyah, 2016; Nessa, Hartono, \& Hiltrimartin, 2017; Wati \& Santosa, 2017). Ketujuh tahapan penelitian dijelaskan sebagai berikut:

\section{Potensi dan Masalah}

Pada tahap ini peneliti memunculkan dan menetapkan masalah yang dihadapi, untuk mengetahui masalah dasar yang dihadapi maka membutuhan data sebagai sumber penunjang penelitian. Data penunjang dari penelitian ini berasal dari kajian literatur dan studi pendahuluan di lapangan.

\section{Pengumpulan Data}

Setelah ditemukan permasalahan, selanjutnya data dikumpulkan untuk dianalisis baik dari segi kurikulum meliputi kajian kedalaman materi, penggunaan media pembelajaran dan evaluasi.

\section{Desain Produk}

Setelah analisis data dilakukan, selanjutnya dibuat rancangan desain dari media pembelajaran Modul Digital 
interaktif Berbasis Articulate Studio'13. Rancangan tersebut kemudian diimplemetasikan menjadi produk awal (prototype).

\section{Validasi Desain}

Langkah selanjutnya setelah produk awal selesai adalah konsultasi kepada tim ahli. Tim ahli yang dibutuhkan untuk melakukan validasi terdiri dari ahli materi, ahli media dan praktisi pendidikan. Ahli materi dan ahli media memvalidasi produk dari aspek-aspek kriteria modul yang telah ditentukan. Sedangkan praktisi pendidikan memvalidasi produk berdasarkan aspek kepraktisan dalam penggunaan.

\section{Revisi Desain}

Setelah validasi produk selesai dilakukan, langkah selanjutnya adalah merevisi produk yang dianggap masih memerlukan perbaikan. Revisi dilakukan berdasarkan saran yang diberikan oleh validator, baik itu ahli materi, ahli media dan praktisi pendidikan.

\section{Uji Coba Produk}

Tahap selanjutnya, setelah produk selesai melalui serangkaian tahap revisi, maka produk kemudian diujicobakan kepada pengguna. Proses uji coba produk merupakan bagian penting dalam penelitian pengembangan yang dilakukan setelah rancangan produk selesai. Uji coba produk dimaksudkan untuk mengumpulkan data yang dapat digunakan sebagai dasar untuk menetapkan tingkat efektifitas, efisiensi dan atau daya tarik dari produk yang dihasilkan. Uji coba produk pada penelitian ini dilakukan dengan dua cara, yaitu uji coba skala terbatas dan uji coba skala luas.

\section{Revisi Produk}

Setelah produk diuji coba, maka dapat diketahui kelemahan dari produk tersebut. Kelemahan tersebut kemudian diperbaiki agar dihasilkan produk yang berkualitas dan siap untuk digunakan.

Instrumen yang digunakan dalam pengumpulan data adalah lembar validasi berupa angket dengan menggunakan skala likert. Lembar validasi pada penelitian ini terdiri atas dari lembar validasi materi, lembar validasi media, lembar validasi praktisi pendidikan, dan lembar angket uji coba kemenarikan. Teknik analisis data sebagai berikut :

a. Mengubah hasil penilaian masih dalam bentuk huruf diubah menjadi skor dengan ketentuan (Basonggo, Tangkas, \& Said, 2014; Asyhari, Sunarno, \& Sarwanto, 2014).

Tabel 1. Pemberian Skor

\begin{tabular}{ccc}
\hline No. & Kategori & Skor \\
\hline 1 & Sangat Baik & 5 \\
2 & Baik & 4 \\
3 & Cukup & 3 \\
4 & Kurang & 2 \\
5 & Sangat Kurang & 1 \\
\hline
\end{tabular}

b. Menghitung persentase kelayakan dari setiap setiap aspek dengan rumus skala likert (Sahfriana, Subchan, \& Suratno, 2015).

$$
x_{i}=\frac{\sum s}{S_{\max }} \times 100 \%
$$

Keterangan:

$\mathrm{S}_{\max }=$ Skor maksimal

$\sum S=$ Jumlah skor

$x_{i}=$ Nilai kelayakan angket tiap aspek

c. Menghitung persentase rata-rata seluruh responden (purwanti dalam (Indrawati, 2013)):

$$
\bar{x}=\frac{\sum_{i=1}^{n} x_{i}}{n}
$$

Keterangan:

$$
\bar{x}=\text { Nilai rata-rata }
$$

$x_{i}=$ Nilai kelayakan angket tiap aspek

$\mathrm{n}=$ Banyaknya pernyataan

d. Mengubah skor rata-rata yang diperoleh menjadi nilai kualitatif yang sesuai dengan kriteria penilaian (Jabar, 2015; Asyhari \& Silvia, 2016). 
Tabel 2. Kriteria Penilaian

\begin{tabular}{cc}
\hline Persentase $(\%)$ & Kriteria \\
\hline $0 \leq X \leq 25$ & Sangat Kurang Layak \\
$25<X \leq 41$ & Kurang Layak \\
$41<X \leq 50$ & Cukup Layak \\
$50<X \leq 75$ & Layak \\
$75<X \leq 100$ & Sangat Layak \\
\hline
\end{tabular}

\section{HASIL DAN PEMBAHASAN Hasil}

Berdasarkan serangkaian langkah pengembangan yang telah dilakukan, maka dihasilkan produk penelitian dan pengembangan berupa modul digital interaktif berbasis Articulate Studio'13 pada materi gerak melingkar kelas $\mathrm{X}$ SMA. Hasil dan pembahasan penelitian dan pengembangan produk ini dijelaskan sebagai berikut.

\section{Potensi Masalah dan Pengumpulan Data}

Potensi masalah dan pengumpulan data diperoleh dari hasil observasi di MAN 1 Bandar Lampung pada pembelajaran fisika bahwa hampir seluruh siswa mempunyai komputer dan sebagian besar peserta didik mempunyai laptop. Namun fasilitas tersebut belum dimanfaatkan dengan baik oleh pendidik. Berdasarkan hasil observasi tersebut peserta didik membutuhkan bahan ajar yang menarik, inovatif dan mudah digunakan untuk menyampaikan pesan dengan baik.

\section{Produk Modul Digital Interaktif}

Modul digital interaktif ini dirancang menyesuaikan dengan karakteristik modul yaitu: Self Instruction, Self Contained, Stand Alone, Adaptive dan User Friendly (Nasional, 2008b). Self Instruction yaitu modul dirancang agar peserta didik mampu belajar mandiri. Self contained yaitu memuat satu unit kompetensi secara utuh. Stand Alone yaitu modul tidak tergantung pada media lain, Adaptive yaitu memiliki daya adaptif terhadap perkembangan ilmu dan teknologi serta fleksibel digunakan. User friendly yaitu bersahabat dengan pemakainya termasuk kemudahan pemakaian, merespon dan mengakses. Beberapa tampilan modul digital interaktif berbasis Articulate studio'13 ditunjukkan pada gambar 3, 4, 5 , dan 6 .

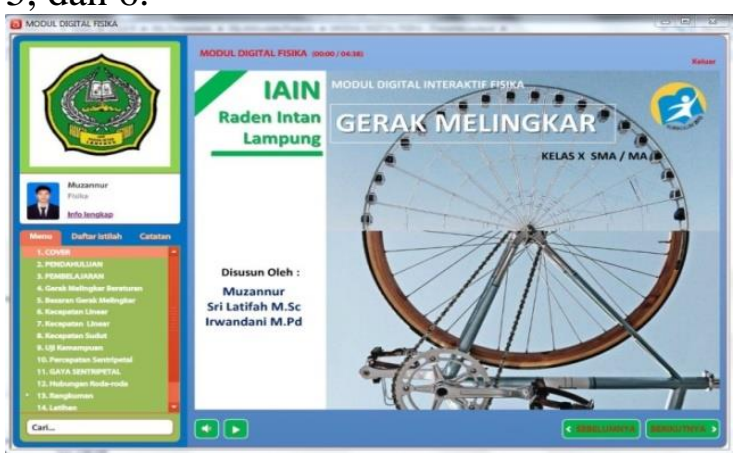

Gambar 3 Tampilan Cover

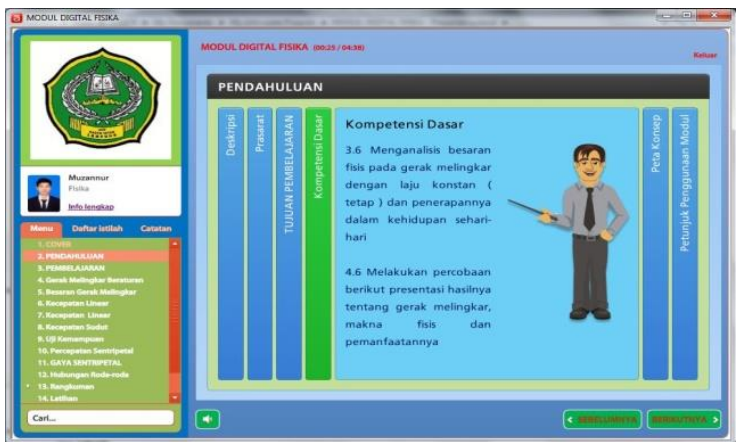

Gambar 4 Tampilan Pendahuluan

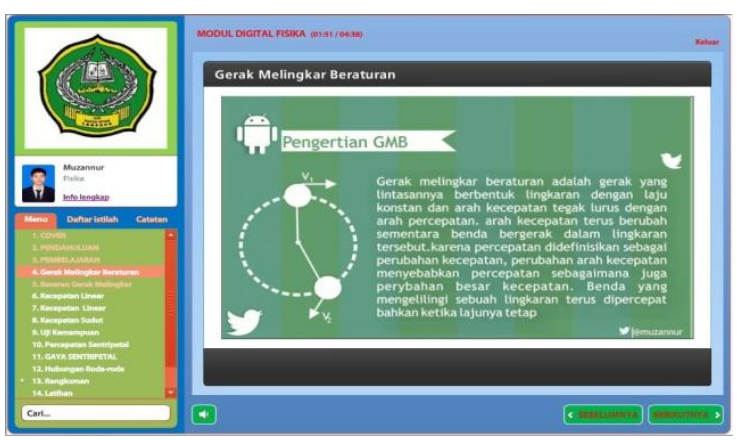

Gambar 5 Tampilan Materi

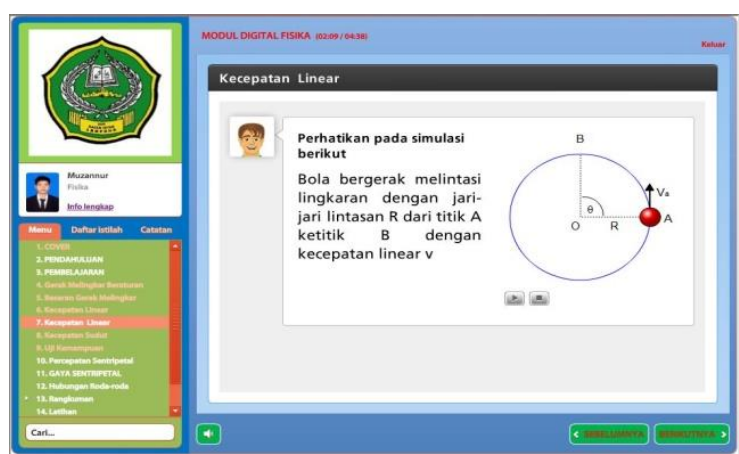

Gambar 6 Tampilan Animasi 


\section{Hasil Validasi}

Produk modul digital interaktif berbasis Articulate studio'13 divalidasi oleh validator berdasarkan bidang keahliannya, yaitu ahli materi, ahli media dan ahli praktisi pendidikan. Validator ahli masing-masing bidang keahliannya terdiri dari tiga orang validator pada masing-masing bidang. Validator materi dan media terdiri dari dosen fisika, dosen pendidikan, dan ahli teknologi pendidikan. Sementara praktisi pendidikan terdiri dari guru fisika di sekolah.

\section{a. Hasil validasi ahli materi}

Validasi ahli materi dilakukan dengan mengisi lembar validasi yang terdiri dari 5 aspek penilaian berdasarkan ketentuan kriteria modul. Butir pernyataan pada instrumen diberikan berdasarkan lima kriteria ditunjukkan pada tabel 3 .

Tabel 3 Hasil Validasi Ahli Materi

\begin{tabular}{ccc}
\multicolumn{3}{c}{ Tabel 3 Hasil Validasi Ahli Materi } \\
\hline Aspek & Skor $(\%)$ & Kategori \\
\hline Self Instruction & 83.3 & Sangat Layak \\
Self Contained & 80.0 & Sangat layak \\
Stand Alone & 86.7 & Sangat Layak \\
Adaptive & 86.7 & Sangat Layak \\
User Friendly & 86.7 & Sangat layak \\
Rata-rata & $\mathbf{8 4 . 6 7}$ & Sangat layak \\
\hline
\end{tabular}

\section{b. Hasil validasi ahli media}

Validasi ahli materi dilakukan dengan mengisi lembar validasi yang terdiri dari 5 aspek penilaian berdasarkan ketentuan kriteria modul. Butir pernyataan pada instrumen diberikan berdasarkan lima kriteria ditunjukkan pada tabel 4 .

Tabel 4. Hasil Validasi Ahli Media

\begin{tabular}{ccc}
\hline Aspek & Skor $(\%)$ & Kategori \\
\hline Self Instruction & 86.0 & Sangat Layak \\
Self Contained & 80.0 & Sangat Layak \\
Stand Alone & 80.0 & Sangat Layak \\
Adaptive & 91.0 & Sangat Layak \\
User Friendly & 90.0 & Sangat Layak \\
Rata-rata & $\mathbf{8 5 . 5 6}$ & Sangat layak \\
\hline
\end{tabular}

\section{c. Hasil validasi praktisi pendidikan}

Validasi praktisi pendidikan dalam hal ini guru fisika dilakukan dengan mengisi lembar angket penilaian yang terdiri dari lima aspek penilaian yaitu, aspek kualitas isi, aspek tampilan modul, aspek kualitas teknis, dan aspek bahasa ditunjukkan pada tabel 5 .

Tabel 5. Hasil Validasi Ahli Praktisi

\begin{tabular}{ccc}
\hline Aspek & Skor(\%) & Kategori \\
\hline Kualitas Isi & 83.3 & Sangat Layak \\
Tampilan & 81.3 & Sangat Layak \\
Kualitas Teknik & 81.7 & Sangat Layak \\
Bahasa & 90.0 & Sangat Layak \\
Rata-rata & $\mathbf{5 6 . 2 5}$ & Sangat Layak \\
\hline
\end{tabular}

\section{Hasil Uji Coba Produk}

Terdapat dua uji coba pada penelitian ini, meliputi uji coba skala kecil dan skala luas.

\section{a. Uji Coba Skala Kecil}

Uji coba kelompok kecil dilakukan kepada 15 peserta didik dengan cara mengisi lembar angket penilaian. Data angket disajikan dalam tabel 6 .

Tabel 6 Hasil Uji Coba Skala Kecil

\begin{tabular}{ccc}
\hline Aspek & $\begin{array}{c}\text { Skor } \\
(\%)\end{array}$ & Kategori \\
\hline Kualitas Isi & 82.0 & Sangat Menarik \\
Tampilan Modul & 84.8 & Sangat Menarik \\
Kualitas Teknik & 80.2 & Sangat Menarik \\
Bahasa & 90.7 & Sangat Menarik \\
Rata-rata & 84.4 & Sangat Menarik \\
\hline
\end{tabular}

\section{b. Uji Coba Skala Luas}

Uji coba skala luas dilakukan kepada 34 peserta didik dengan cara mengisi lembar angket penilaian. Data angket disajikan dalam tabel 7.

Tabel 7 Hasil Uji Coba Skala Luas

\begin{tabular}{clc}
\hline Aspek & Skor(\%) & Kategori \\
\hline Kualitas Isi & $84 . .2$ & Sangat Menarik \\
Tampilan Modul & 82.6 & Sangat Menarik \\
Kualitas Teknik & 86.1 & Sangat Menarik \\
Bahasa & 87.3 & Sangat Menarik \\
Rata-rata & $\mathbf{8 5 . 0}$ & Sangat Menarik \\
\hline
\end{tabular}

Perbedaan persentase kemenarikan tidak terlalu signifikan berdasarkan kedua uji coba tersebut dan masing-masing memperoleh persentase $\geq 80 \%$. Sehingga dapat disimpulkan menunjukkan bahwa secara umum penilaian berdasarkan uji 
coba kualitas produk sangat layak pada skala kecil maupun luas.

\section{Pembahasan}

Penyajian hasil pengembangan ini bertujuan untuk menjawab rumusan masalah. Data-data yang disajikan merupakan deskripsi dari serangkaian proses pengembangan, hasil validasi kelayakan dan hasil uji coba.

Penilaian oleh ahli materi dalam bentuk tabel dan grafik. Dari data hasil validasi ahli materi pada masing-masing aspek bahwa modul digital yang dikembangkan dikategorikan sangat layak untuk digunakan, hal ini terlihat dari hasil penilaian masing-masing aspek yang memperoleh skor diatas $80 \%$, dengan persentase rata-rata $84.67 \%$. Dengan demikian modul digital interaktif berbasis articulate studio'13 dinyatakan sangat layak untuk digunakan dari sisi materi.

Kategori sangat layak pada sisi materi karena sudah sesuai dengan kriteria modul. Pada aspek self instruction modul yang dikembangkan sudah memenuhi kriteria antara lain: tersedia tujuan pembelajaran, contoh dan ilustrasi, soalsoal yang relevan dengan materi, rangkuman, dan instrumen penilaian. Pada aspek self contained modul yang dikembangkan sudah memuat seluruh materi dan satu kompetensi dasar gerak melingkar secara utuh. Pada aspek stand alone modul tidak bergantung pada bahan ajar yang lain. Pada aspek adaptive materi modul mengikuti perkembangan kurikulum. Pada aspek user friendly materi disajikan sistematis, logis, mudah dipahami dan mudah digunakan.

Penilaian ahli media dengan angket persentase rata-rata kelayakan produk adalah $85.56 \%$. Dengan demikian modul digital interaktif berbasis articulate studio'13 sangat layak dari sisi penyajian media.

Prodak media dengan kategori sangat layak, sesuai dengan kriteria modul. Pada aspek self instruction antara lain: pengemasan materi sangat baik, tersedia petunjuk penggunaan modul, bahasa yang digunakan sederhana dan komunikatif, tersedia umpan balik atas penilaian, dan mendukung untuk pembelajaran mandiri. Pada aspek self contained modul memudahkan peserta didik mempelajari materi secara tuntas dan mensimulasikan konsep-konsep gerak melingkar. Aspek stand alone bahwa modul independent dan softwere modul digital dapat disimpan dalam compact disk atau sejenisnya. Pada aspek adaptive modul mengadaptasi perkembangan teknologi. Pada aspek user friendly Intruksi mudah digunakan dan mudah dalam merespon dan mengakses konten modul.

Penilaian praktisi pendidikan terhadap modul digital interaktif berbasis articulate studio' 13 persentase kelayakan rata-rata $84.1 \%$. Dengan demikian modul yang dikembangkan dinyatakan sangat layak untuk digunakan sebagai bahan belajar bagi peserta didik menurut penilaian guru fisika.

Modul digital dari aspek kualitas isi materi sesuai dengan kompetensi dasar, dan materi mendukung, pencapaian Kompetensi Dasar (KD). Aspek tampilan modul, penampilan unsur tata letak dan pilihan warna pada modul proporsional dan menarik, sajian materi video dan gambar menarik, teks, gambar dan simulasi jelas, gambar pada modul membantu mengingat materi yang dipelajari, gambar, simulasi dan ilustrasi yang disajikan efisien untuk meningkatkan pemahaman peserta didik.

Aspek kualitas teknis modul digital dapat digunakan dengan mudah, urutan penyampaian materi tersusun secara konsisten sistematis, konsep disajikan secara runtut, bersifat interaktif dan partisipatif. Pada aspek bahasa, bahasa yang digunakan sesuai perkembangan peserta didik dan kaidah bahasa. 


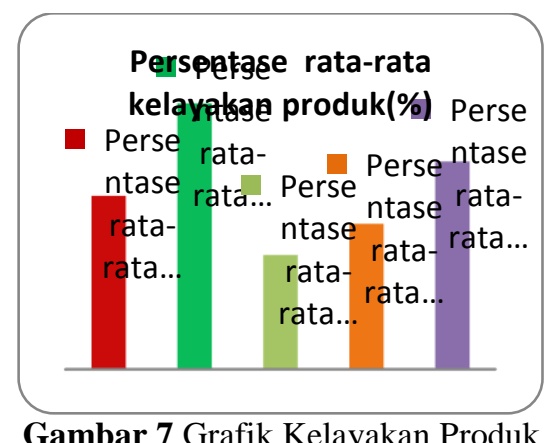

Gambar 7 Grafik Kelayakan Produk

Gambar 7 menunjukkan bahwa modul yang telah dikembangkan dikategorikan "sangat layak" dan "sangat menarik" untuk digunakan sebagai modul digital interaktif pada pembelajaran.

Kelebihan modul digital interaktif berbasis Articulate Studio'13 antara lain: 1) Mampu menyajikan materi pembelajaran dengan menampilkan video, simulasi dan animasi tentang konsep yang dipelajari; 2) Memiliki tampilan visual yang baik dan menarik, sehingga bisa menarik peserta didik untuk mempelajari fisika; 3) Modul dilengkapi dengan kuis yang menyajikan soal-soal secara interaktif sehingga membantu siswa menguji kemampuan dan evaluasi secara mandiri; 4) Modul sangat praktis karena berupa softwere komputer yang bisa disimpan dalam sebuah compact disk dan removable disk lainnya.

\section{SIMPULAN DAN SARAN}

\section{Simpulan}

Berdasarkan hasil dan pembahasan dapat disimpulkan bahwa: 1) Penelitian ini menghasilkan produk berupa Modul Digital Interaktif Berbasis Articulate Studio'13 Pada materi gerak melingkar kelas X SMA; 2) Kualitas dan kelayakan menurut para ahli yaitu sangat layak dari hasil validasi pada format materi dengan persentase skor rata-rata $80.4 \%$ persentase ahli media, $82.85 \%$ menurut ahli praktisi $84.1 \%$; 3) Respon peserta didik terhadap kemenarikan Modul sangat menarik dengan persentase rata-rata dalam skala kecil dan skala luas masing- masing diperoleh skor rata-rata yakni $84,40 \%$ dan $85.00 \%$.

\section{Saran}

Adapun Saran untuk pengguna dan penelitian selanjutnya yakni: 1) Penelitian dan pengembangan perlu ditindak lanjuti lagi untuk penelitian dibidang pengembangan bahan ajar yang lebih baik lagi; 2) Modul Digital Interaktif Berbasis Articulate Studio'13 yang dikembangkan dapat digunakan disekolah sebagai salah satu penunjang pembelajaran sehingga bermanfaat; 3) Modul Digital Interaktif Berbasis Articulate Studio'13 yang dikembangkan hanya pada materi gerak melingkar untuk SMA/MA kelas X saja, selanjutnya perlu dikembangkan lebih lanjut untuk materi yang lain dengan konten yang lebih variatif.

\section{DAFTAR PUSTAKA}

Aprilliyah, \& Wahjudi, E. (2014). Pengembangan Media Pembelajaran Modul Interaktif pada Materi Jurnal Khusus Kelas X Akutansi di SMK Negeri Mojoagung. UNESA, 1-7.

Asyhari, A., \& Diani, R. (2017). Pembelajaran Fisika Berbasis Web Enhanched Course: Mengembangkan Web-Blogs Pembelajaran Fisika Dasar I. Jurnal Inovasi Teknologi Pendidikan, 4(1), 13-25. doi:10.21831/jitp.v4i1.13435

Asyhari, A., \& Silvia, H. (2016). Pengembangan Media Pembelajaran Berupa Buletin dalam Bentuk Buku Saku untuk Pembelajaran IPA Terpadu. Jurnal Ilmiah Pendidikan Fisika Al-BiRuNi, 5(I), 1-13. doi:10.24042/jpifalbiruni.v5i1.100

Asyhari, A., Irwandani, I., \& Saputra, H. C. (2016). Lembar Kerja Instruksi Konseptual Berbasis PhET: Mengembangkan Bahan Ajar untuk Mengkonstruksi Konsep Siswa Pada Efek Fotolistrik. Jurnal Ilmiah Pendidikan Fisika 'Al-BiRuNi', 5(2), 
193-204.

doi:10.24042/jpifalbiruni.v5i2.119

Asyhari, A., Sunarno, W., \& Sarwanto, S. (2014). Pengembangan Perangkat Pembelajaran Fisika SMA Berbasis Inkuiri Terbimbing Terintegrasi Pendidikan Karakter. Jurnal Inkuiri, 3(1), 62-75.

Aulliyah, M., Sutarto, \& Harijanto, A. (2015). Paket Sumber Belajar dengan Analisis Wacana Isu untuk Pembelajaran Fisika. Jurnal Pendidikan Fisika, 4(2), 152-158.

Ayudia, C. (2014). Upaya kepala sekolah dalam meningkatkanpartisipasi orang tua di sdn kecamatan pariaman utara kota pariaman. Jurnal Administrasi Pendidikan Halaman, 2(1), 100-107.

Basonggo, I., Tangkas, I. M., \& Said, I. (2014). Meningkatkan Hasil Belajar Siswa Melalui Metode Eksperimen dalam Pembelajaran IPA di Kelas V SDN Meselesek. Jurnal Kreatif Tadulako Online, 2(2), 96-104.

Byun, J., Sung, T. E., \& Park, H. W. (2017). Technological innovation strategy: how do technology life cycles change by technological area. Technology Analysis and Strategic Management, $1-15$. https://doi.org/10.1080/09537325.20 17.1297397

Desy, Desnita, \& Raihanati. (2015). Pengembangan Alat Peraga Fisika Materi Gerak Melingkar untuk SMA. Prosiding Seminar Nasional Fisika (E-Journal) SNF2015, IV, 39-44.

Fachrory Akbar Ghozali. (2016). Pengembangan Media Pembelajaran Berbasis Articulate Studio'13 Kompetensi Dasar Arsitektur dan Prinsip Kerja Fungsi Setiap Blok PLC di SMK Negeri 1Sampang. Jurnal Pendidikan Teknik Elektro, 5(1).

Fathurohman, A. (2014). Analogi dalam pengajaran fisika. Jurnal Inovasi Dan Pembelajaran Fisika, 1(1), 7477.
Heeks, R., \& Stanforth, C. (2015). Technological change in developing countries: Opening the black box of process using actor-network theory. Development Studies Research, 2(1), 33-50. https://doi.org/10.1080/21665095.20 15.1026610

Huda, T. A., Fadiawati, N., \& Tania, L. (n.d.). Pengembangan E-Book Interaktif Pada Materi Termokimia Berbasis Rerresentasi Kimia, 26-37.

Indrawati, R. M. (2013). Peningkatan Aktivitas dan Hasil Belajar Materi Peristiwa Sekitar Proklamasi Melalui Bermain Peran. Journal of Elementary Education, 2(4), 15-22.

Irwandani, I., \& Juariyah, S. (2016). Pengembangan Media Pembelajaran Berupa Komik Fisika Berbantuan Sosial Media Instagram sebagai Alternatif Pembelajaran. Jurnal Ilmiah Pendidikan Fisika Al-Biruni, 5(1), 33. https://doi.org/10.24042/jpifalbiruni. v5i1.103

Jabar, A. (2015). Penerapan Pendekatan Problem Posing untuk Meningkatkan Kemampuan Pemecahan Masalah. Math Didactic: Jurnal Pendidikan Matematika, 1(2), 81-88.

Krismiyati. (2017). Pengembangan Sumber Daya Manusia dalam Meningkatkan Kualitas Pendidikan di SD Negeri Inpres Angkasa Biak. Jurnal Office, 3(1), 43-50.

Kristanti, Y. D., Subiki, \& Handayani, R. D. (2016). Model Pembelajaran Berbasis Proyek (Project Based Learning Model) Pada Pembelajaran Fisika SMA. Jurnal Pembelajaran Fisika, 5(2), 122-128.

Lubis, S. A., \& Derlina. (2016). Pengaruh Model Pembelajaran Generatif terhadap Hasil Belajar Siswa pada Materi Pokok Hukum Newton di SMP Yayasan Perguruan Budi Agung Medan Marelan T.P. 2013/2014. Jurnal Inpafi, 4(4), 140- 
145.

Nasional, D. P. (2008a). Panduan Pengembangan Bahan Ajar. Jakarta: Direktorat Jendral Manajemen Pendidikan Dasar dan Menengah.

Nasional, D. P. (2008b). Penulisan Modul. Jakarta: Direktorat Tenaga Kependidikan Direktorat Jendral Peningkatan Mutu dan Tenaga Kependidikan Dinas.

Nessa, W., Hartono, Y., \& Hiltrimartin, C. (2017). Pengembangan Buku Siswa Materi Jarak Pada Ruang Dimensi Tiga Berbasis Science, Technology, Engineering, And Mathematics ( STEM ) ProblemBased Learning Di Kelas X. Jurnal Elemen, 3(1), 1-14.

Ngafifi, M. (2014). Kemajuan Teknologi dan Pola Hidup Manusia dalam Perspektif Sosial Budaya. Jurnal Pembangunan Pendidikan: Fondasi Dan Aplikasi, 4(1), 33-47.

Nurul Qomariah. (2012). Pengaruh Kualitas Layanan dan Citra Institusi terhadap Kepuasan dan Loyalitas Pelanggan (Studi pada Universitas Muhammadiyah di Jawa Timur). Jurnal Aplikasi Manajemen, 10(1), 177-.

P, A. B., Sunaryo, \& Iswanto, B. H. (2012). Pengembangan Media Pembelajaran Fisika Berbasis Adobe Flash untuk Menjelaskan Fisika Inti dan Radioaktivitas untuk SMA Kelas XII. Seminar Nasional Fisika, 116120.

Permana, M. S., Johar, D., \& Bunyamin. (2014). Pengembangan Media Pembelajaran Interaktif Ilmu Pengetahuan Alam (IPA) Berbasis Multimedia. Jurnal Algoritma, 11(1), $1-10$.

Praswoto, A. (2014). Pengembangan Bahan Ajar Tematik. Yogyakarta: Kencana Media Group.

Purnamasari, P., An'nur, S., \& M., A. S. (2016). Pengembangan Bahan Ajar melalui Model Pembelajaran
REACT pada Materi Elastisitas. Berkala Ilmiah Pendidikan Fisika, 4(3), 209-221.

Rahayu, S. D., Prihandono, T., \& Gani, A. A. (2017). Pengembangan Modul Fisika Berbasis Concept Mapping pada Materi Elastisitas di SMA. Jurnal Pembelajaran Fisika, 6(3), 247-254.

Sahfriana, I., Subchan, W., \& Suratno. (2015). Penerapan Model Pembelajaran Group Investigation (GI) dalam Meningkatkan Kemampuan Berpikir Kritis dan Keterampilan Sosial Siswa dalam Pembelajaran IPA Biologi untuk Materi Ajar Pertumbuhan dan Perkembangan Kelas 8-C Semester Gasal di SMP Negeri 1 Bangil . Pancaran, 4(2), 213-222.

Sari, D. M., Surantoro, \& Ekawati, E. Y. (2013). Analisis Kesalahan dalam Menyelesaikan Soal Materi Termodinamika Pada Siswa SMA. Jurnal Materi Dan Pembelajaran Fisika (JMPF), 3(1), 5-8.

Sugianto, D., Abdullah, A. G., Elvyanti, S., \& Muladi, Y. (2013). Modul Virtual: Multimedia Flipbook Dasar Teknik Digital. INVOTEC, IX(2), 101-116.

Sugiono. (2011). Metode Penelitian Kuantitatif, Kualitatif dan $R \& D$. Bandung: Alfabeta.

Sujanem, R., Suswandi, I., \& Ganesha, U. P. (2012). Pengembangan Modul Software Multimedia Interaktif dengan Strategi Pembelajaran Berbasis Masalah untuk Meningkatkan Pemahaman Konsep dan Hasil Belajar Fisika Siswa Kelas XII SMA. Jurnal Pendidikan Indonesia |, 1(1), 13-27.

Suprapto. (2006). Peningkatan Kualitas Pendidikan Melalui Media Pembelajaran Menggunakan Teknologi Informasi di Sekolah. Jurnal Ekonomi \& Pendidikan, 3(April), 34-41. 
Suroso. (2016). Analisis Kesalahan Siswa dalam Mengerjakan Soal-soal Fisika Termodinamika pada Siswa SMA Negeri 1 Magetan. JEMS (Jurnal Edukasi Matematika Dan Sains), 4(1), 8-18.

Syafi'i, M., \& Nasir, M. (2016). Perancangan dan Pembangunan Multimedia Interaktif Pembelajaran Fisika Visualisasi Gerak Melingkar Beraturan Di Sekolah Menengah Atas (SMA). Jurnal Pendidikan, 8696.

Tania, L., \& Susilowibowo, J. (2017). Pengembangan Bahan Ajar E-Modul sebagai Pendukung Pembelajaran Kurikuum 2013 pada Materi Ayat Jurnal Penyesuain Perusahaan Jasa SIswa Kelas $\mathrm{X}$ Akutansi SMK Negeri 1 Surabaya. UNESA, 1-9.

Ulfah, M. (2012). Mekanisme Perolehan Ilmu dalam Perspektif Filsafat
Pendidikan Islam. Jurnal Ilmiah DIDAKTIKA, XII(2), 289-307.

Wati, P. A., \& Santosa, A. B. (2017). Pengembangan Lks Berbasis Proyek Pada Mata Pelajaran Kerja Bengkel Dan Menggambar Teknik Kelas X Smk Kal-1 Surabaya. Jurnal Pendidikan Teknik Elektro, 6(3), 401-407.

Wulandari, R., Susilo, H., \& Kuswandi, D. (2016). Multimedia Interaktif Bermuatan Game Edukasi Sebagai Salah Satu Alternatif Pembelajaran IPA Di Sekolah Dasar. Jurnal Pendidikan, 1-8.

Yoto, Zulkardi, \& Wiyono, K. (2015). Pengembangan Multimedia Interaktif Pembelajaran Teori Kinetik Gas Berbantuan Lectora Inspire untuk Siswa Sekolah Menengah Atas (SMA). Jurnal Inovasi Dan Pembelajaran Fisika, 2(2), 211-219. 